\title{
Ammonia volatilization from blends with stabilized and controlled-released urea in the coffee system
}

\author{
Volatilização de amônia de blends com ureia estabilizada e de \\ liberação controlada no cafeeiro
}

\author{
Wantuir Filipe Teixeira Chagas ${ }^{1}$, Douglas Ramos Guelfi ${ }^{\star *}$, André Luiz Carvalho Caputo', \\ Taylor Lima de Souza², André Baldansi Andrade', Valdemar Faquin ${ }^{1}$
}

${ }^{1}$ Universidade Federal de Lavras/UFLA, Departamento de Ciência do solo, Lavras, MG, Brazil

¿Universidade Federal de Lavras/UFLA, Lavras, MG, Brazil

${ }^{*}$ Corresponding author: douglasguelfi@dcs.ufla.br

Received in March 9, 2016 and approved in July 18, 2016

\begin{abstract}
Application of stabilized and controlled-release urea blends can reduce the losses of $\mathrm{N}^{-\mathrm{NH}_{3}}$ as compared to conventional urea. The aim of this study was to quantify ammonia volatilization from conventional nitrogen fertilizers and blends of urea + (urea + NBPT) + controlled release urea applied in drip irrigated coffee system. The experiment was conducted under field conditions in in a Red Latosol located in Lavras-MG, Brazil. The randomized complete block design with six treatments: Urea $=450 \mathrm{~kg}$ ha-1 $\mathrm{yr}^{-1} \mathrm{~N}\left(100 \%\right.$ of the recommended dose) divided in three splittings equal to $150 \mathrm{~kg} \mathrm{ha}^{-1} \mathrm{~N}$ with an interval of 50 days; ammonium nitrate $=450 \mathrm{~kg} \mathrm{ha}^{-1} \mathrm{yr}^{-1} \mathrm{~N}(100 \%$ of the recommended dose $)$ in three splittings equal to $150 \mathrm{~kg} \mathrm{ha}^{-1} \mathrm{~N}$ with an interval of 50 days; Polyblen Extend ${ }^{-}-100 \%=450 \mathrm{~kg} \mathrm{ha}^{-1} \mathrm{yr}^{-1}\left(100 \%\right.$ of the recommended dose) applied in two splittings, $315 \mathrm{~kg}$ ha-1 $\mathrm{N}$ in the $1^{\circ} \mathrm{split}$ and $135 \mathrm{~kg} \mathrm{ha}^{-1} \mathrm{~N}$ in the $2^{\circ}$ split; Polyblen Extend ${ }^{\circledR}-70 \%=315 \mathrm{~kg} \mathrm{ha}^{-1} \mathrm{yr}^{-1} \mathrm{~N}$ (70\% of the recommended dose) in two splittings, 220.5 $\mathrm{kg} \mathrm{ha}{ }^{-1} \mathrm{~N}$ in the $1^{\circ}$ split and $94.5 \mathrm{~kg} \mathrm{ha}^{-1} \mathrm{~N}$ in the $2^{\circ}$ split; Polyblen Montanha ${ }^{\circledR}-100 \%=450 \mathrm{~kg} \mathrm{ha}^{-1} \mathrm{yr}^{-1}(100 \%$ of the recommended dose) in an unique application in the $1^{\circ}$ split and Polyblen Montanha ${ }^{\circledR}-70 \%=315 \mathrm{~kg} \mathrm{ha}^{-1} \mathrm{yr}^{-1} \mathrm{~N}(70 \%$ of the recommended dose) at an unique application in the $1^{\circ}$ split, with three repetitions. Total accumulated $\mathrm{N}^{-\mathrm{NH}_{3}}$ losses followed the decreasing order: Urea $\left(83.2 \mathrm{~kg} \mathrm{ha}^{-1} \mathrm{~N}\right)>$ Polyblen Extend ${ }^{\circledR}-100 \%\left(60.3 \mathrm{~kg} \mathrm{ha}^{-1} \mathrm{~N}\right)>$ Polyblen Montanha $^{\circledR}-100 \%\left(46.8 \mathrm{~kg} \mathrm{ha}{ }^{-1} \mathrm{~N}\right)>$ Polyblen $^{-1}$ Extend ${ }^{\circledR}-70 \%$ $\left(35.1 \mathrm{~kg} \mathrm{ha}^{-1} \mathrm{~N}\right)>$ Polyblen Montanha ${ }^{\circledR}-70 \%\left(24.2 \mathrm{~kg} \mathrm{ha}^{-1} \mathrm{~N}\right)>$ nitrate ammonium $\left(2.0 \mathrm{~kg} \mathrm{ha}^{-1} \mathrm{~N}\right)$. The use of Polyblen Montanha ${ }^{\circledR}$ decreases two splittings compared to conventional sources such as urea and ammonium nitrate, by applying only $70 \%$ of the recommended dose without affecting yield and coffee crop nutrition.
\end{abstract}

Index terms: Irrigation; nitrogen fertilizer technologies; polymer-sulfur coated urea.

\begin{abstract}
RESUMO
A aplicação de blends de ureia com inibidor de urease e de liberação controlada pode reduzir as perdas de $\mathrm{N}^{-\mathrm{NH}_{3}}$ em comparação a ureia convencional. O objetivo desse trabalho foi quantificar as perdas de $\mathrm{N}^{-\mathrm{NH}_{3}}$ por fertilizantes nitrogenados convencionais e "blends" de ureia + (ureia + NBPT) e ureia de liberação controlada aplicados em lavoura cafeeira irrigada por gotejamento. O experimento foi realizado em condições de campo em um Latossolo Vermelho de textura argilosa, Lavras - MG, Brasil. O delineamento foi em blocos casualizados com seis tratamentos: Ureia $=450 \mathrm{~kg} \mathrm{ha}^{-1} \mathrm{ano}^{-1}$ de $\mathrm{N}(100 \%$ da dose recomendada) dividido em três parcelamentos iguais de $150 \mathrm{~kg} \mathrm{ha}^{-1}$ de $\mathrm{N}$ com intervalo de 50 dias; Nitrato de amônio $=450 \mathrm{~kg} \mathrm{ha}^{-1} \mathrm{ano}^{-1} \mathrm{de} \mathrm{N}(100 \%$ da dose recomendada) em três parcelamentos iguais de $150 \mathrm{~kg} \mathrm{ha}^{-1}$ de $\mathrm{N}$ com intervalo de 50 dias; Polyblen Extend ${ }^{\circledR}-100 \%=450 \mathrm{~kg} \mathrm{ha}^{-1} \mathrm{ano}^{-1}(100 \%$ da dose recomendada) aplicado em dois parcelamentos, $315 \mathrm{~kg} \mathrm{ha}^{-1} \mathrm{de} \mathrm{N}$ no $1^{\circ}$ parcelamento e $135 \mathrm{~kg} \mathrm{ha}{ }^{-1} \mathrm{de} \mathrm{N}$ no $2^{\circ}$ parcelamento; Polyblen Extend $^{\circledR}-70 \%=315 \mathrm{~kg} \mathrm{ha}^{-1} \mathrm{ano}^{-1}$ de $\mathrm{N}\left(70 \%\right.$ da dose recomendada) em dois parcelamentos, $220,5 \mathrm{~kg} \mathrm{ha}^{-1}$ de $\mathrm{N}$ no $1^{\circ}$ parcelamento e $94,5 \mathrm{~kg} \mathrm{ha}^{-1}$ de N no $2^{\circ}$ parcelamento; Polyblen Montanha ${ }^{\circledR}-100 \%=450 \mathrm{~kg} \mathrm{ha}^{-1}$ ano-1 (100\% da dose recomendada) em aplicação única no $1^{\circ}$ parcelamento e o Polyblen Montanha ${ }^{\circledR}-70 \%=315 \mathrm{~kg} \mathrm{ha}^{-1} \mathrm{ano}^{-1} \mathrm{de} \mathrm{N}(70 \%$ da dose recomendada) em aplicação única no $1^{\circ}$ parcelamento, com três repetições. A perda acumulada total de $\mathrm{N}-\mathrm{NH}_{3}$ seguiu a ordem decrescente: Ureia $(83,2 \mathrm{~kg} \mathrm{ha-1}$ de N)> Polyblen Extend ${ }^{\circledR}-100 \%\left(60,3 \mathrm{~kg} \mathrm{ha}^{-1} \mathrm{de} \mathrm{N}\right)>$ Polyblen Montanha ${ }^{\circledR}-100 \%\left(46,8 \mathrm{~kg} \mathrm{ha}^{-1} \mathrm{de} \mathrm{N}\right)>$ Polyblen Extend $^{\circledR}-70 \%\left(35,1 \mathrm{~kg} \mathrm{ha}^{-1}\right.$ de N) > Polyblen Montanha ${ }^{\circledR}-70 \%\left(24,2\right.$ kg ha-1 de N) > nitrato de amônio (2,0 kg ha-1 de N). Com a utilização do Polyblen Montanha ${ }^{\circledR}$ é possível reduz dois parcelamentos em comparação a fontes convencionais como uréia e nitrato de amônio, aplicando-se apenas $70 \%$ da dose recomendada sem alterar a produtividade e a nutrição do cafeeiro.
\end{abstract}

Termos para indexação: Irrigação; tecnologias de fertilizantes nitrogenados; ureia revestida com enxofre e polímeros. 


\section{INTRODUCTION}

Agronomic coffee growing holds a prominent position in Brazilian agricultural, generating jobs and bringing revenue into the country. The coffee plant yield is influenced by several factors, including the nutritional status of the plants. The nitrogen nutrition of the coffee tree deserves special attention because nitrogen $(\mathrm{N})$ is the nutrient required in the greatest amount and the second most exported nutrient in grains (Carelli et al., 2006; Fenilli et al, 2007; Bruno et al, 2011; Martinez et al., 2014).

In Brazil in 2014, 830,374 metric tons of $\mathrm{N}$ as urea were produced, and another 1,644,545 metric tons were imported, totaling 2,474,919 metric tons of $\mathrm{N}$ (ANDA, 2015). Thus, of the total $\mathrm{N}$ delivered to farmers, $64 \%$ was applied as urea. Economic factors related to the production and logistics processes make urea the most used nitrogen fertilizer in the world. Due to the high concentration of $\mathrm{N}$ (45\%), urea has a lower cost per unit $\mathrm{N}$ compared to that of sulfate and ammonium nitrate (Roy; Hammond, 2004; Fernandes et al., 2015).

However, in relation to its agronomic aspects, when urea is applied to the soil surface without any incorporation, significant losses by volatilization may occur, reaching average values of $30 \%$ of the total applied $\mathrm{N}$ (Dominghetti et al., 2016) and thus changing the availability of $\mathrm{N}$ to the coffee plants (Fenilli et al., 2007).

To reduce ammonia $\left(\mathrm{N}^{-\mathrm{NH}_{3}}\right)$ losses of urea and maintain an adequate availability of $\mathrm{N}$ in soil, different strategies related to the best practices for the efficient use of fertilizers (Chien; Prochnow; Cantarella, 2009; IFA 2009; Rochette et al., 2014) and fertilizer technologies (Azeem et al., 2014; Timilsena et al., 2015) can be used. Among these are the use of urease inhibitors, such as (NBPT), and the coating of urea with elemental sulfur $\left(\mathrm{S}^{\circ}\right)$ and resins or polymers. However, one factor limiting the use of these technologies is the price. Controlled-release and stabilized fertilizers have higher market values than does conventional urea (Trenkel, 2010, Chen et al., 2011). This is a major limitation to its use on a larger scale (Azeem et al., 2014; Timilsena et al., 2014.).

Thus, an alternative to this problem would be the combined use (blends) of conventional urea (urea), controlled-release urea (coated urea) and urease inhibitors (Trenkel, 2010). The use of the physical mixture of conventional fertilizers, stabilized or controlled-release (blends), aims to a) reduce the cost of labor and machinery; b) reduce $\mathrm{N}$ losses by volatilization, leaching and denitrification and increase efficiency in the use of N; c) decrease the number of splits of $\mathrm{N}$ fertilization; and $\mathrm{d}$ ) seek a release of fertilizer nutrients in synchronization with the absorption curve of the crop throughout the cycle (Crew; Peoples, 2005; Funjinuma; Balster; Normam, 2009; Jin et al., 2013; Azeem et al., 2014).

The timing between the release and absorption of $\mathrm{N}$ can lead to a reduction in the cost of labor in coffee crops because the "blend" when produced at appropriate ratios among the nitrogen fertilizers will supply the nutrient throughout the coffee plant fertilization cycle (November to March) to meet the nutrient requirements of the plant.

It is also possible to reduce the number of splits of $\mathrm{N}$ fertilizer from 3 to 4 times during the rainy season, as recommended by Guimarães et al. (1999), to one or two applications. Among the main factors that control the $\mathrm{N}$ fertilizer release speed are temperature and soil moisture (Du; Zhou; Shaviv, 2006; Du et al., 2008; Fan; Li, 2010) and the type and thickness of the urea coating (Chen et al., 2011; Azeem et al., 2014.).

Despite the importance of the use of a physical mixture of conventional, stabilized and controlled-release nitrogen fertilizers, studies indicate that evaluate the use of blends with different technologies in addition to urea are still scarce (Noellsch et al., 2009; Grant et al., 2012) in areas with coffee plants. In this context, the present study was conducted to quantify the losses of $\mathrm{N}-\mathrm{NH}_{3}$ by conventional $\mathrm{N}$ fertilizers (urea and ammonium nitrate) and physical mixtures of granules (blends) of urea + (urea + NBPT) and controlled-release urea applied in drip irrigated coffee system.

\section{MATERIAL AND METHODS}

The experiment was conducted in the field between August 2014 and August 2015 on soil classified as a dystroferric Red Latosol, equivalent to an Oxisol at US Soil Taxonomy Classification System (Buol et al., 2011; EMBRAPA, 2013), on a commercial coffee farm in Lavras, state of Minas Gerais, Brazil. The climate according to the Köppen classification system is classified as Cwa, with a dry winter and rainy summer (Alvares et al., 2013), an average annual rainfall of approximately $1,530 \mathrm{~mm}$ and a mean annual temperature of $19.4^{\circ} \mathrm{C}$ (Dantas; Carvalho; Ferreira, 2007). The rainfall, concentrated between October and March, was followed by a long dry spell in the remaining six months. The climatic data are from the continuous monitoring of rainfall events during the rainy season from November to March at the main weather station of Lavras, approximately $1 \mathrm{~km}$ apart from the research site. In a period of experiment was measured soil temperature and humidity. 
Before setting up the experiment, soil samples were collected from a depth of 0-0.02 $\mathrm{m}$. To prepare the analysis, sods were broken into fine particles, and the soil was sieved using a $4 \mathrm{~mm}$ mesh sieve and let to air-dry. The soil was further sieved through a $2 \mathrm{~mm}$ mesh sieve, and sub-samples were taken for chemical and physical analyses, which were conducted according to the methodology of the Soil Fertility Committee of Minas Gerais State - CFSEMG (1999), Brazil (Table 1).

The experiment was performed in a completely randomized block design with three replications and included the following treatments (Table 2).

The experimental plots consisted of 12 plants per cultivar Catuaí IAC 74, 6 year after transplanting seedlings, equally spaced $3.7 \mathrm{~m}$ between rows and 0.9 $\mathrm{m}$ between plants. The harvest area contained 10 plants, excluding the two ends and the two lateral rows as borders.
The characteristics of the fertilizers were as follows: (a) Urea - granular urea (45-00-00) of $\mathrm{N}$ and (b) Ammonium nitrate - granular with (30-00-00); (c) Polyblen Extend ${ }^{\circledR}$ and Polyblen Montanha ${ }^{\circledR}$ (Blend) granular urea coated with an elemental sulfur layer plus an organic polymer that acts like a sealing wax to the sulfur layer and another part in the form of conventional granular urea $+530 \mathrm{mg} \mathrm{kg}^{-1}$ NBPT (stabilized urea). The coated urea of the blends represents the controlledrelease nitrogen due to a physical barrier that prevents its dissolution in water. The total nitrogen content was 39\%, with $12 \%$ elemental sulfur $\left(\mathrm{S}^{0}\right)$ content. The difference between Polyblen Extend ${ }^{\circledR}$ and Polyblen Montanha ${ }^{\circledR}$ is in the thickness of the coating layer with sulfur. Polyblen Extend ${ }^{\circledR}$ presents a layer thickness ranging from 67 to 68 $\mu \mathrm{m}$, while that of Polyblen Montanha ${ }^{\mathbb{B}}$ ranges from 87 to $99 \mu \mathrm{m}$ (Figure 1).

Table 1: Soil chemical analysis and particle size distribution (0-0.02 $\mathrm{m})$ of an area of drip irrigated coffee crop system.

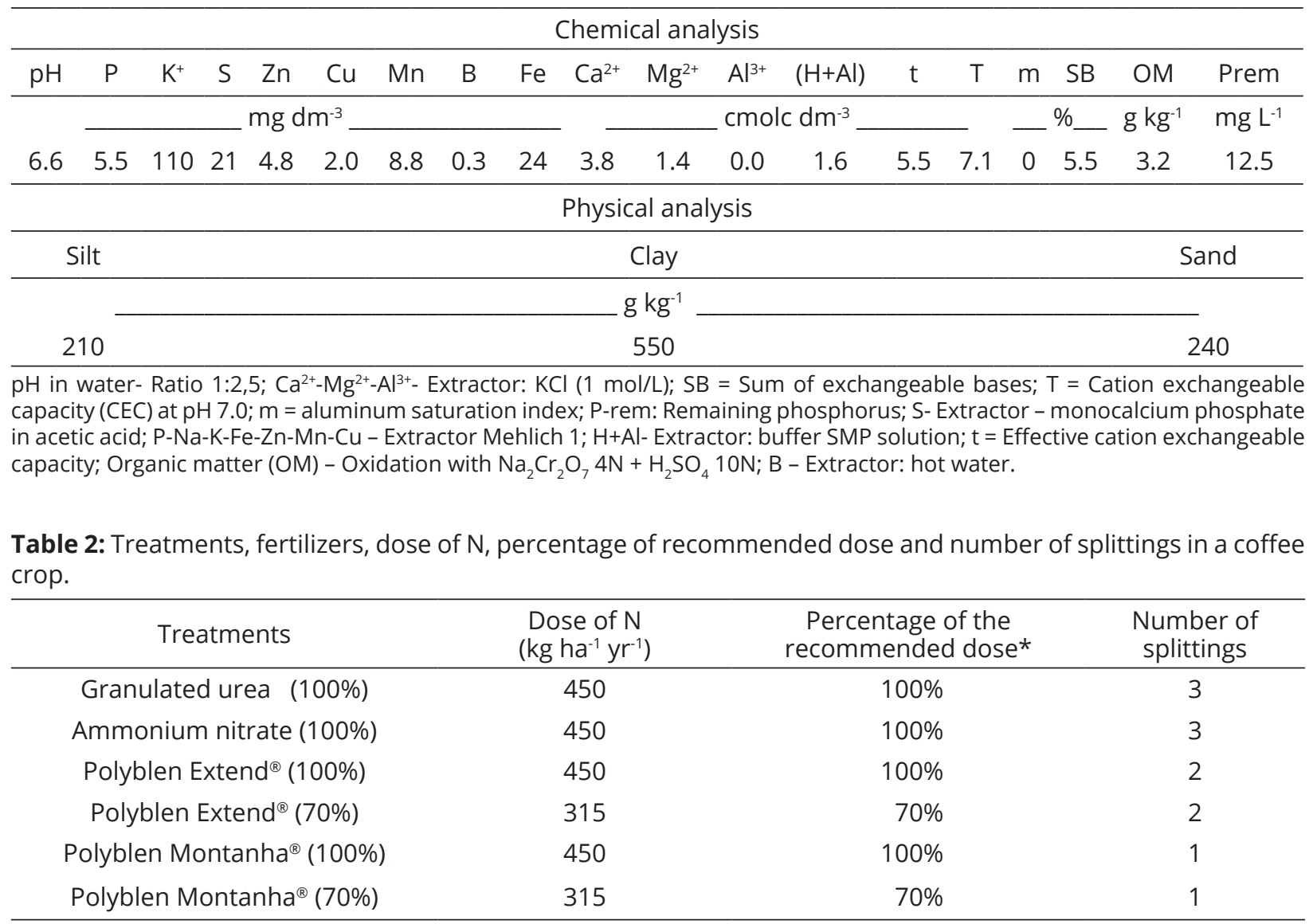

*Recommended dose $=450 \mathrm{~kg} \mathrm{~N}^{-1}$ year $^{-1}$ (Guimarães et al., 1999). 


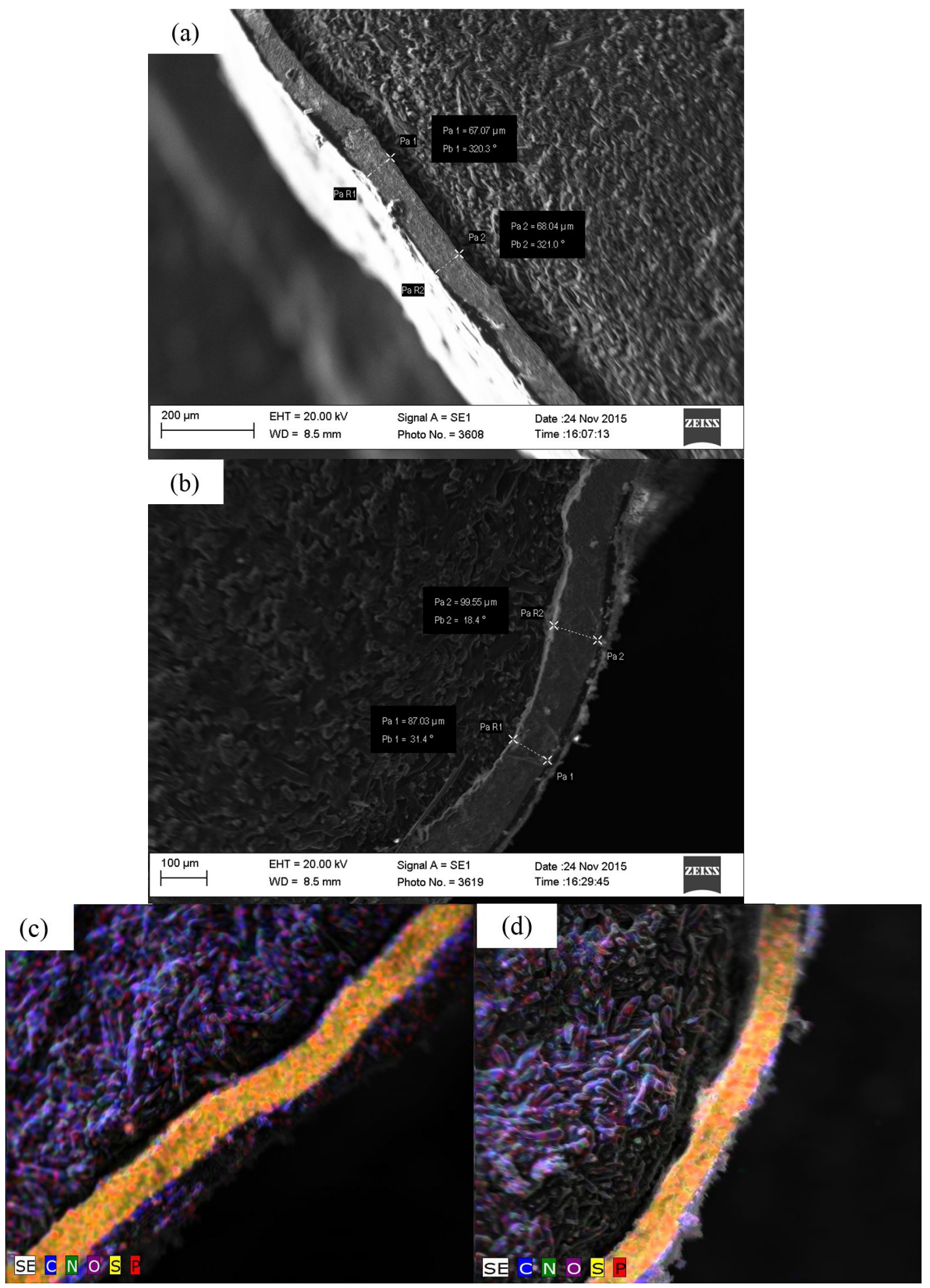

Figure 1: Electron micrograph which characterizes the thickness of the coating of urea $S^{0}$ - Polyblen Extend ${ }^{\circledR}$ : - 67$68 \mu \mathrm{m}$ (a) Polyblen Montanha ${ }^{\circledR}: 87$ to $99 \mu \mathrm{m}$ (b) and their respective EDS for carbon (C), nitrogen (N), oxygen (O), phosphorus (P) and sulfur (S) (c and d). 
By presenting a greater layer thickness of sulfur compared to that of Polyblen Extend ${ }^{\circledR}(67-68 \mu \mathrm{m})$, Polyblen Montanha $^{\circledR}$ (87 to $99 \mu \mathrm{m}$ ) allows a controlled release of $\mathrm{N}$ for a longer period, which is why it is recommended by the manufacturer for a unique application, excluding splittings. It is indicated for coffee crops, mainly in areas where topography hampers mechanization (according to manufacturer, $\mathrm{N}$ is released for up to six months).

In the treatments with the application of $\mathrm{N}$ as urea and ammonium nitrate, the recommended dose $(450 \mathrm{~kg} \mathrm{~N}$ $\mathrm{ha}^{-1} \mathrm{yr}^{-1}$ ) was split into three applications of $150 \mathrm{~kg} \mathrm{~N} \mathrm{ha}^{-1}$ (Guimarães et al., 1999), with a 50 day interval between each fertilization, at the following dates: 22/11/2014; $12 / 01 / 2015$ and 03/03/15. The treatments Polyblen Extend $\left(100 \%\right.$ of the recommended dose) and Polyblen Extend ${ }^{\circledR}$ ( $70 \%$ of the recommended dose) were split into two applications: $70 \%$ of the $\mathrm{N}$ applied in the first fertilization $(22 / 11 / 2014)$ and $30 \%$ of the remaining $\mathrm{N}$ applied in the second fertilization (12/01/2015). The treatments Polyblen Montanha ${ }^{\circledR}(100 \%$ of the recommended dose) and Polyblen Montanha ${ }^{\circledR}(70 \%$ of the recommended dose) had no split of fertilization, and all of the $\mathrm{N}$ was applied in a single dose at the beginning of the experiment (22/11/2014).

The treatments were applied manually and in the projection of the canopy according to the recommendations for coffee crop (Guimarães et al., 1999). The standard of splittings into treatments with Polyblen Extend ${ }^{\circledR}$ and Polyblen Montanha ${ }^{\circledR}$ was established according to the recommendation of the manufacturer: two splittings to Polyblen Extend ${ }^{\circledR}$ and a unique application to Polyblen Montanha ${ }^{\circledR}$.

The maintenance fertilization for coffee was as follows: $249 \mathrm{~kg} \mathrm{~K} \mathrm{ha}^{-1}$ as potassium chloride $(60 \%$ $\left.\mathrm{K}_{2} \mathrm{O}\right)$ split into three doses applied every 50 days from $22 / 11 / 2014$ onwards. The source of phosphate fertilizer (Triple superphosphate - $46 \% \mathrm{P}_{2} \mathrm{O}_{5}$ ) was applied at one single rate of $44 \mathrm{~kg} \mathrm{P} \mathrm{ha}^{-1}$. The micronutrients boron, zinc and copper were applied via foliar spray.

Irrigation management was performed according to data obtained from the Lavras weather station, following the methodology used by Vieira et al. (2011), using Irriplus $^{\odot}$ software. The soil of the experimental area is classified as a Red Latosol (LV) (EMBRAPA, 2013).

The rate of ammonia volatilization was determined using a semi-static open collector adapted from Lara Cabezas, Korndörfer and Motta (1999). Polyvinyl chloride tubes, $0.20 \mathrm{~m}$ in diameter and $0.50 \mathrm{~cm}$ long, were inserted into the soil at $0.05 \mathrm{~m}$ in depth and located under the tree canopy $35 \mathrm{~cm}$ from the plagiotropic branch). Two rubber foam discs, $0.02 \mathrm{~g} \mathrm{~cm}^{-3}$ in density and $0.025 \mathrm{~m}$ thick, of the same diameter as the tubes were imbibed in phosphoric acid
$\left(\mathrm{H}_{3} \mathrm{PO}_{4}\right)$ and glycerin and put into tubes 0.25 and $0.45 \mathrm{~cm}$ from the soil. Foams were soaked with $85 \mathrm{~mL}$ of phosphoric acid solution $\left(\mathrm{H}_{3} \mathrm{PO}_{4}\right)$ and glycerin at concentrations of 40 and $58.8 \mathrm{~mL} \mathrm{~L}^{-1}$, respectively. The phosphoric acid concentration was $0.87 \mathrm{~mol} \mathrm{~L}^{-1}$. The upper foam protected the lower foam from contamination. The lower foam, placed $0.25 \mathrm{~m}$ from the soil, was used to determine the volatilized ammonia. Evaluations on volatilized ammonia were conducted at $1 ; 2 ; 3 ; 4 ; 5 ; 7 ; 9 ; 11 ; 13 ; 16 ; 19 ; 23 ; 28$; 35; and 42 days after each $\mathrm{N}$ fertilization on the following dates $11 / 22 / 2014 ; 01 / 12 / 2015$; and 03/03/15. After each fertilization, all of the lower foams were exchanged, including in treatments that applied the total dose of $\mathrm{N}$ in the first fertilization $(11 / 22 / 2014)$ and that presented losses of less than $0.1 \%$ of $\mathrm{N}$.

The determination of $\mathrm{N}$, captured from volatilization, was carried out as follows: the foams were washed with distilled water over a porous tile Buchner funnel with the help of a vacuum pump. The volume extracted from the foams was measured; aliquots were transferred to test tubes and distilled in a semi-micro Kjeldahl apparatus (Dominghetti et al., 2016).

In the beginning of the experiment $(11 / 20 / 2014)$ and at the time of harvesting $(07 / 15 / 15)$, leaves were sampled for $\mathrm{N}$ content analysis. The $3^{\circ}$ pair of leaves from the apex of productive branches, located in the medium portion of the plants, was sampled (CFSEMG, 1999).

Before harvesting $(07 / 15 / 15)$, the SPAD index was also measured (Soil and Plant Analysis Development) by readings taken with a SPAD-502 chlorophyll meter in the middle third of the leaf, sampled in the $3^{\text {rd }}$ pair of leaves from the apex of productive branches, located in the middle portion of the plants.

For harvesting (07/15/2015 and 07/16/2015), it was considered useful to plant five plants per plot, with the excluding two lines as borders.

After harvesting, the following were calculated: a) Yield, being the volume of harvested coffee (known as "café da roça") required to produce a final bag of $60 \mathrm{~kg}$ of benefited coffee, and b) Income, being the volume of bean coffee required to produce $1.0 \mathrm{~kg}$ of benefited coffee.

Coffee, after being harvested, processed and benefited, was submitted to assessments based in the physical features of size and shape using the rating by sieve.

The sorting by sieve was determined according to the shape and size of the grains of coffee. According to shape, the coffee grains are classified into flat and moca. Flat grains had a dorsal convex surface and were ventral, flat or slightly concave with central a groove longitudinally, and the moca grains presented an ovoid shape, also with a central groove in the longitudinal direction. 
Granulometry was determined by the sieves, according to the grain size and the size of the screens that hold them, being circular for flat grains and oblong for "moca" grains (Brazil, 2003). The coffee grains were classified by sieve size into large shot flat grain (Sieves 17, 18 and 19), medium flat grain (Sieves 15 and 16), kid flat grain (Sieves 14 and lower) and "moca" grain (Brasil, 2003).

All of the data were submitted to an analysis of variance (ANOVA), and the means were compared by a Skott-Knott test $(\mathrm{a}=0.05)$. An ANOVA was performed after checking the normality (Shapiro-Wilk's test) and homogeneity of variance (Bartlett's test) of the data. Statistical analyses were performed using the statistical analysis software SISVAR $5.6^{\circledR}$ (Ferreira, 2011).

\section{RESULTS AND DISCUSSION}

The accumulated and daily losses of ammonia $\left(\mathrm{N}-\mathrm{NH}_{3}\right)$ were influenced $(\mathrm{p} \leq 0.05)$ by the $\mathrm{N}$ fertilizers applied to the coffee plant. The accumulated (Figure 2a) and daily (Figure 2b) losses of $\mathrm{N}^{-\mathrm{NH}_{3}}$ associated with rainfall, air and soil temperature, relative humidity and volumetric soil moisture 42 days after the $1^{\text {st }}$ fertilization are shown in Figure 2c.

The accumulated loss of $\mathrm{N}^{-\mathrm{NH}_{3}} 42$ days after the $1^{\text {st }}$ fertilization followed the decreasing order: Polyblen Montanha $^{\circledR}-100 \%\left(41.9 \mathrm{~kg} \mathrm{~N} \mathrm{ha}^{-1}-9.3 \%\right.$ of the applied $\left.\mathrm{N}\right)$ $=$ Polyblen Extend ${ }^{\circledR}-100 \%$ (38.8 $\mathrm{kg} \mathrm{N} \mathrm{ha}^{-1}-12.3 \%$ of the applied $\mathrm{N})>$ Urea $\left(23.2 \mathrm{~kg} \mathrm{~N} \mathrm{ha}^{-1}-15.5 \%\right.$ of the applied $\mathrm{N})=$ Polyblen Extend ${ }^{\circledR}-70 \%\left(23.1 \mathrm{~kg} \mathrm{~N} \mathrm{ha}^{-1}-10.5 \%\right.$ of the applied $\mathrm{N})=$ Polyblen Montanha ${ }^{\circledR} 70 \%\left(20.0 \mathrm{~kg} \mathrm{~N} \mathrm{ha}^{-1}\right.$ $-6.4 \%$ of the applied $\mathrm{N})>$ ammonium nitrate $\left(0.9 \mathrm{~kg} \mathrm{~N} \mathrm{ha}^{-1}\right.$ $-0.6 \%$ of the applied N) (Figure 1a). The greatest losses of $\mathrm{N}^{-\mathrm{NH}_{3}}$ from Polyblen Montanha ${ }^{\circledR}-100 \%$ (450 kg N ha ${ }^{-1}$ applied at one split) and Polyblen Extend ${ }^{\circledR}-100 \%$ (450 $\mathrm{kg} \mathrm{N} \mathrm{ha}{ }^{-1}$ applied at two splits: $70 \% \mathrm{~N}$ in the $1^{\text {st }}$ nitrogen fertilization and $30 \%$ in the $2^{\text {nd }}$ ) is based on a reduction in the number of splits compared to that of conventional urea (450 $\mathrm{kg} \mathrm{N} \mathrm{ha}^{-1}$ applied at three equal splits).

The accumulated rainfall 42 days after the $1^{\text {st }}$ nitrogen fertilization was $335.4 \mathrm{~mm}$. In the first seven days, the period in which the greatest losses of $\mathrm{N}-\mathrm{NH}_{3}$ occurred after the application of urea to the surface, the rainfall was $3.5 ; 0 ; 1.4 ; 3.4 ; 5.0 ; 71.4$; and 11.1 millimeters $(\mathrm{mm})$ and the soil moisture was $22.2 ; 21.8 ; 21.0 ; 22.1 ; 22.4$; 26.2 ; and $23.3 \%$. During the same period, the average air temperature was $23.0^{\circ} \mathrm{C}$ and that of the soil was $21.7^{\circ} \mathrm{C}$.

The values of relative humidity in the air were greater than $74.3 \%$ (critical relative humidity of urea) in the first (80\%), second (83\%), third (85\%), fourth $(83 \%)$, fifth $(84 \%)$, sixth $(82 \%)$ and seventh $(81 \%)$ days after the application of nitrogen fertilizers, with the occurrence of low rainfall and soil moisture (Figure 1c). These factors contributed to the peak of $\mathrm{N}$ volatilization of urea ( $5.6 \%$ of the applied $\mathrm{N}-8.4 \mathrm{~kg} \mathrm{~N} \mathrm{ha}^{-1}$ ) occurring on day three after application (Figure $1 \mathrm{~b}$ ). $\mathrm{N}^{-N_{3}}$ loss peaks in coffee crops occurred between the $1^{\text {st }}$ and $3^{\text {rd }}$ days after the application of urea in amounts equivalent to $5.0 \%, 8.4 \%$, and $9.1 \%$ of the total $\mathrm{N}$ applied $\left(450 \mathrm{~kg} \mathrm{~N} \mathrm{ha}^{-1}\right)$ in each of the three fertilizations ( $\left.150 \mathrm{~kg} \mathrm{~N} \mathrm{ha}^{-1}\right)$ (Dominghetti et al., 2016).

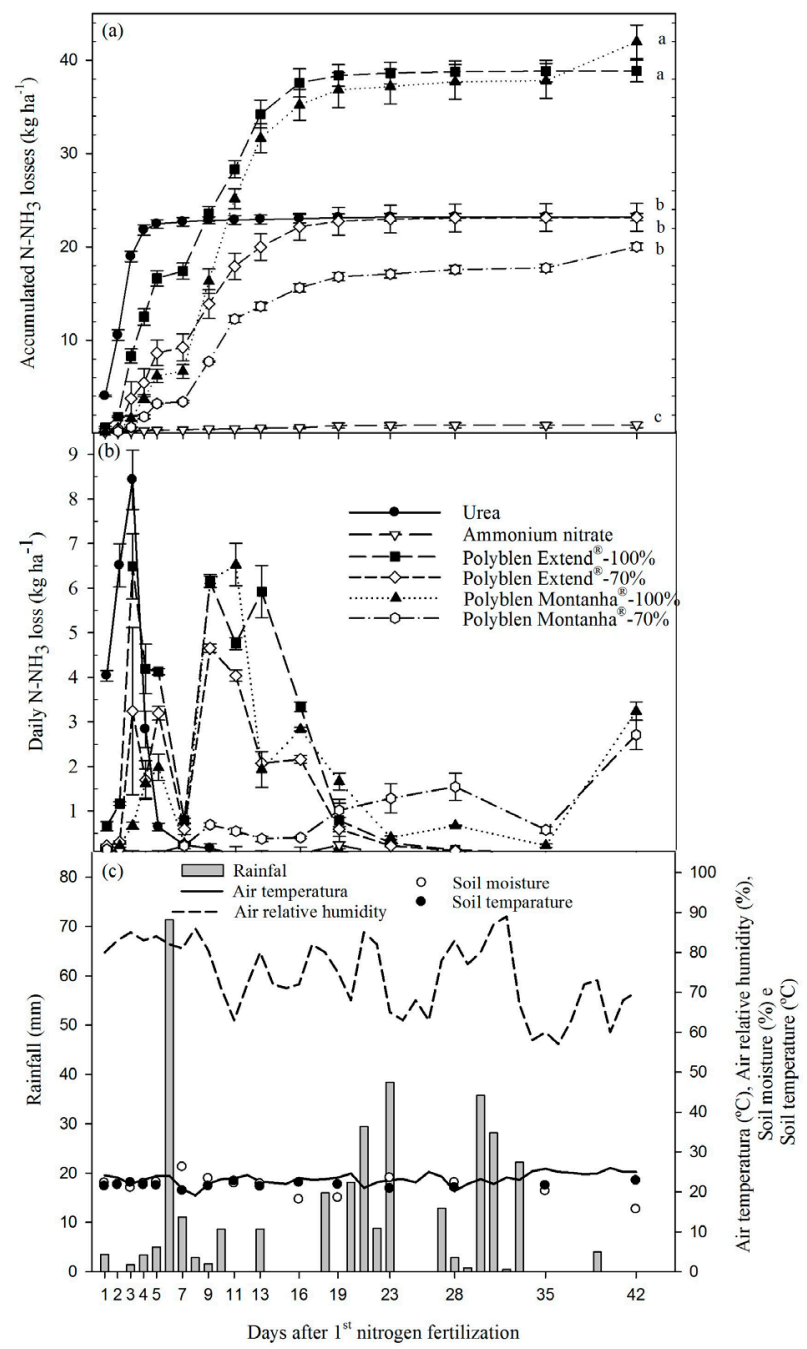

Figure 2: Accumulated (a) and daily (b) $\mathrm{N}^{-\mathrm{NH}_{3}}$ losses from fertilizers (conventional urea, ammonium nitrate, Polyblen Extend ${ }^{\circledR}$ and Polyblen Montanha ${ }^{\circledR}$ ) after $1^{\text {st }}$ nitrogen fertilization in drip irrigated coffee system related to climate data (c). The equal letters do not differ from one another by the Skott-Knott test at $5 \%$ significance level. The vertical bars represent the standard error of the mean $(n=3)$. 
The urea blends with NBPT and polymer sulfur-coated urea (Polyblen Extend ${ }^{\circledR}-100 \%$, Polyblen Extend $^{\circledR}-70 \%$, Polyblen Montanha ${ }^{\circledR}-100 \%$ and Polyblen Montanha ${ }^{\circledR}-70 \%$ ) had the maximum possible daily losses of $\mathrm{N}_{-} \mathrm{NH}_{3}$ equal to $6.5 \mathrm{~kg} \mathrm{Nha}^{-1}(2 \%$ of the applied $\mathrm{N}) ; 4.6$ $\mathrm{kg} \mathrm{N} \mathrm{ha}^{-1}(2.1 \%$ of the applied $\mathrm{N}) ; 6.5 \mathrm{~kg} \mathrm{~N} \mathrm{ha}^{-1}(1.4 \%$ of $\mathrm{N}$ applied) and $2.7 \mathrm{~kg} \mathrm{~N} \mathrm{ha}^{-1}(0.9 \%$ of the applied $\mathrm{N}) 3$, 9,11 and 42 days after the $1^{\text {st }}$ fertilization, respectively.

The delay in the loss peak of $\mathrm{N}^{-\mathrm{NH}_{3}}$ by the blends (Polyblen Extend ${ }^{\mathbb{B}}$ and Polyblen Montanha ${ }^{\mathbb{B}}$ ) compared to that of conventional urea is related to the time of nutrient release by fertilizers due to changes in the urea dissolution rate due to the addition of coating with $\mathrm{S}^{0}+$ polymers. The controlled release fertilizers (urea $+\mathrm{S}^{0}+$ polymers) release $\mathrm{N}$ gradually through the diffusion of fertilizer granules into the soil solution depending on temperature, soil moisture and type and thickness of the coating (Chen et al., 2011). Thus, $\mathrm{N}$ is less susceptible to losses in the first few days after application. However, conventional urea, because it is highly soluble in water, hydrolyzes faster (Azeem et al., 2014; Dominghetti et al., 2016).

Among the blends used, the largest coating thickness $\left(\mathrm{S}^{0}+\right.$ polymers $)$ of Polyblen Montanha ${ }^{\circledR}$ ranging from 87-99 $\mu \mathrm{m}$ compared to Polyblen Extend ${ }^{\circledR}$, at 67-68 $\mu \mathrm{m}$ (Figure 1), enabled a delay in the urea dissolution process (Figure $2 b$ ).

Ammonium nitrate did not promote daily loss peaks of N-NH $\mathrm{N}_{3}$ (Figure 1b), and the accumulated loss of $\mathrm{N}-\mathrm{NH}_{3}$ in the $1^{\text {st }}$ fertilization (Figure 1a) was $0.9 \mathrm{~kg} \mathrm{~N} \mathrm{ha}^{-1}$, the lowest among all of the fertilizers applied.

The gradual release of $\mathrm{N}$ of the coated urea may be considered an advantage in relation to ammonium nitrate due to the timing between the release and nutrient absorption by the coffee plant. The use of coated urea can provide a synchronized release of the nutrient by the fertilizer with the crop demand throughout the entire cycle (Dominghetti et al., 2016). This synchronism may allow for a reduction of costs regarding staff during fertilization because the fertilizer will supply the nutrient throughout the entire cycle of coffee crop fertilization, thus avoiding the requirement of three splittings, as recommended by Guimarães et al. (1999).

After the $2^{\text {nd }}$ nitrogen fertilization, the accumulated loss of $\mathrm{N}-\mathrm{NH}_{3}(\%)$ followed the order: urea $\left(32.8 \mathrm{~kg} \mathrm{~N} \mathrm{ha}^{-1}-\right.$ $21.8 \%$ of applied N) $>$ Polyblen Extend ${ }^{\circledR}-100 \%(21.4 \mathrm{~kg} \mathrm{~N}$ ha $^{-1}-15.9 \%$ of applied $\left.\mathrm{N}\right)>$ Polyblen Extend $^{\circledR}-70 \%(11.6 \mathrm{~kg}$ $\mathrm{N} \mathrm{ha}^{-1}-12.3 \%$ of applied N) $>$ Polyblen Montanha ${ }^{\circledR}-100 \%$ $\left(5.5 \mathrm{~kg} \mathrm{~N} \mathrm{ha}^{-1}-1.2 \%\right.$ of applied $\left.\mathrm{N}\right)=$ Polyblen Montanha ${ }^{\circledR}-$ $70 \%\left(4.3 \mathrm{~kg} \mathrm{~N} \mathrm{ha}^{-1}-1.3 \%\right.$ of applied $\left.\mathrm{N}\right)>$ ammonium nitrate $\left(0.6 \mathrm{~kg} \mathrm{~N} \mathrm{ha}^{-1}-0.4 \%\right.$ of applied N) (Figure 2a).
The rainfall that accumulated in these 42 days after the $2^{\text {nd }}$ fertilization was $246.6 \mathrm{~mm}$. In the first seven days after the application of urea to the surface, there was no rainfall and the relative humidity in the air was below the critical relative humidity of urea (Figure $2 \mathrm{c}$ ).

Urea had a volatilization peak (11.1 $\mathrm{kg} \mathrm{N} \mathrm{ha}^{-1}-7.4 \%$ of the applied N) as early as the $2^{\text {nd }}$ day after its application (Figure 2b), and this peak higher than the peak of the $1^{\text {st }}$ fertilization $\left(8.4 \mathrm{~kg} \mathrm{~N} \mathrm{ha}^{-1}-5.6 \%\right.$ of the applied $\left.\mathrm{N}\right)$, where the maximum value of $\mathrm{N}_{-} \mathrm{NH}_{3}$ loss occurred on day 3 (Figure $1 b)$. The soil moisture decreased from the $1^{\text {st }}$ to the $2^{\text {nd }}$ day, where there was the greatest loss of $\mathrm{N}^{-\mathrm{NH}_{3}}$ of urea.

Although in the nine days after the application of fertilizers no rainfall occurred, on the day prior to the $2^{\text {nd }}$ fertilization and on the $6^{\text {th }}$ day afterwards, the irrigation system was turned and provided a depth of water equal to $9 \mathrm{~mm}$ for each application. The measured soil moisture was $21.8 ; 19.2 ; 18.7 ; 18.2 ; 18.0 ; 20.2$; and $19.2 \%$ on the $1^{\text {st }} ; 2^{\text {nd. }} ; 3^{\text {rd }} ; 4^{\text {th }} ; 5^{\text {th }} ; 7^{\text {th }}$; and $9^{\text {th }}$ days after the $2^{\text {nd }}$ fertilization, respectively. In the same period, the average air temperature was $23{ }^{\circ} \mathrm{C}$, and the measured soil temperature was 22.2 ; $22.8 ; 23.1 ; 22.5 ; 22.6 ; 21.2$ and $22{ }^{\circ} \mathrm{C}$ (Figure 3c). The relative air humidity in this period in which there was no rainfall $(53 ; 62 ; 53 ; 55 ; 52 ; 44 ; 47 ; 45$ and; $54 \%)$ was always below the critical relative humidity of urea $(74.3 \%)$.

The $\mathrm{N}_{-} \mathrm{NH}_{3}$ loss peak of urea during this period without rainfall and relative air humidity below the critical humidity of urea is associated with variations in the moisture and evaporation of soil water. The held irrigation increased the soil moisture to $21.8 \%$ in the first day after the $2^{\text {nd }}$ nitrogen fertilization, with a subsequent decrease in moisture until the $5^{\text {th }}$ day after treatment application to $18 \%$. Several studies (Mclnnes et al., 1986; Hargrove et al., 1987; Lara Cabezas; Trivelin; Boaretto, (1992), including those cited by Cantarella (2007), have reported that the largest losses of $\mathrm{N}^{-\mathrm{NH}_{3}}$ occur when the soil surface is drying.

The maximum daily loss of $\mathrm{N}-\mathrm{NH}_{3}$ from Polyblen Extend $^{\circledR}$ - 100\% (4.8 kg N ha $\left.{ }^{-1}\right)$ and Polyblen Extend ${ }^{\circledR}$ $70 \%\left(2.7 \mathrm{~kg} \mathrm{~N} \mathrm{ha}^{-1}\right)$ occurred on day 3 after the $2^{\text {nd }}$ split of $\mathrm{N}$ fertilization $(30 \%$ of the total dose of nitrogen provided in the agricultural year 2014/2015). In the $2^{\text {nd }} \mathrm{N}$ fertilization, urea and ammonium nitrate were applied at a dose of 150 $\mathrm{kg} \mathrm{N} \mathrm{ha}^{-1}$, and in the treatments Polyblen Extend ${ }^{\circledR}-100 \%$ and Polyblen Extend ${ }^{\circledR}-70 \%$, they were applied at 135 and $94.5 \mathrm{~kg} \mathrm{~N} \mathrm{ha}^{-1}$. However, in the treatments with Polyblen Montanha $^{\circledR}-100 \%$ and $70 \%$ Polyblen Montanha ${ }^{\circledR}$, there was no $\mathrm{N}$ application (without split). Thus, with the application of Polyblen Montanha ${ }^{\circledR}-100 \%$ and Polyblen Montanha $^{\circledR}$ - $(70 \%)$ accumulated, the losses of $\mathrm{N}-\mathrm{NH}_{3}$ 
(Figure 3a) were related to the portion of the $\mathrm{N}$ applied still in the $1^{\text {st }}$ fertilization with no splits $\left(450 \mathrm{~kg} \mathrm{~N} \mathrm{ha}^{-1}\right)$.

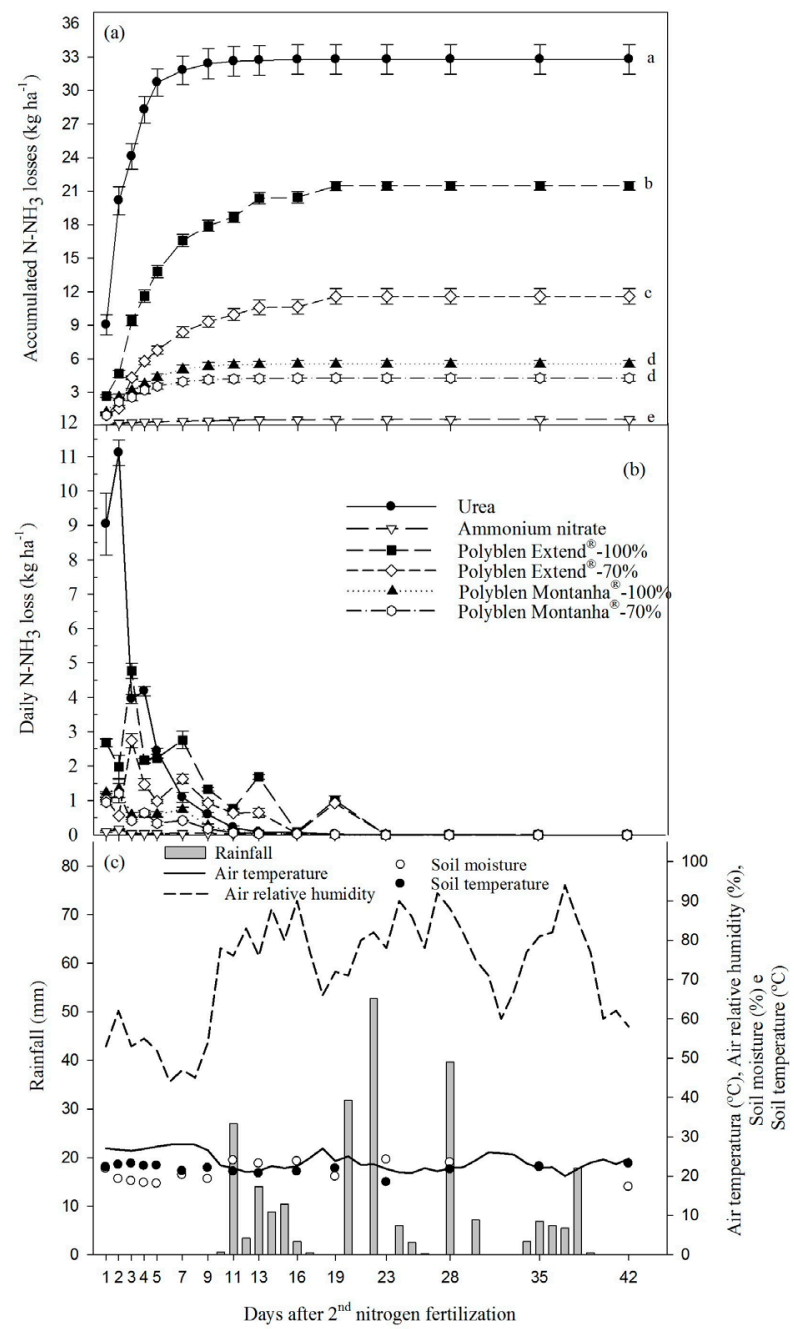

Figure 3: Accumulated (a) and daily (b) $\mathrm{N}-\mathrm{NH}_{3}$ losses from fertilizers (conventional urea, ammonium nitrate, Polyblen Extend ${ }^{\circledR}$ and Polyblen Montanha ${ }^{\circledR}$ ) after $2^{\text {nd }}$ nitrogen fertilization in drip irrigated coffee system related to climate data (c). The equal letters do not differ from one another by the Skott-Knott test at $5 \%$ significance level. The vertical bars represent the standard error of the mean $(n=3)$.

Ammonium nitrate, such as in the $1^{\text {st }}$ fertilization, did not promote daily loss peaks of $\mathrm{N}^{-\mathrm{NH}_{3}}$ or the lowest accumulated loss of $\mathrm{N}\left(0.6 \mathrm{~kg} \mathrm{~N} \mathrm{ha}^{-1}\right)$ among the fertilizers (Figure 2b). The accumulated loss of $\mathrm{N}^{-\mathrm{NH}_{3}}$ 42 days after the $3^{\text {rd }} \mathrm{N}$ fertilization with urea was $27.4 \mathrm{~kg}$ $\mathrm{N} \mathrm{ha}^{-1}\left(18.2 \%\right.$ of the $\mathrm{N}$ applied) and $0.7 \mathrm{~kg} \mathrm{~N} \mathrm{ha}^{-1}(0.5 \%$ of $\mathrm{N}$ applied) for ammonium nitrate. The other fertilizers did not promote losses during this period because the treatments Polyblen Montanha ${ }^{\circledR}$ and Extend ${ }^{\circledR}$ were not applied in the $3^{\text {rd }}$ fertilization due to the reduction in the number of splits, showing that they had no $\mathrm{N}-\mathrm{NH}_{3}$ losses of the residual of the previous fertilizations (Figure 4a).

In the $3^{\text {rd }}$ fertilization, urea promoted a daily maximum volatilization of $8.7 \mathrm{~kg} \mathrm{~N}^{-1}$ on the $4^{\text {th }}$ day after its application on the soil surface (Figure 4b). This

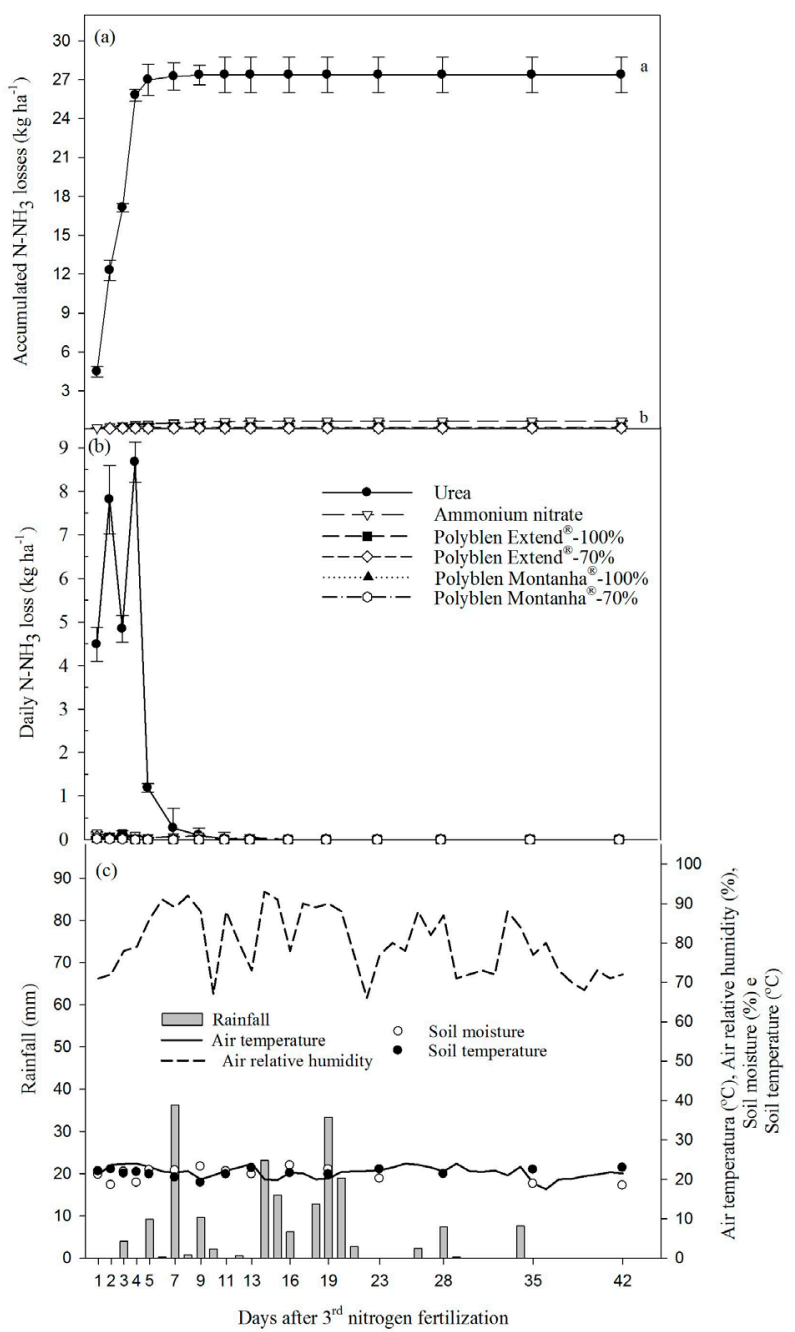

Figure 4: Accumulated (a) and daily (b) $\mathrm{N}^{-\mathrm{NH}_{3}}$ losses from fertilizers (conventional urea, ammonium nitrate, Polyblen Extend ${ }^{\circledR}$ and Polyblen Montanha ${ }^{\circledR}$ ) after $3^{\text {rd }}$ nitrogen fertilization in drip irrigated coffee system related to climate data (c). The equal letters do not differ from one another by the Skott-Knott test at $5 \%$ significance level. The vertical bars represent the standard error of the mean $(n=3)$. 
behavior differs from that observed in the first two nitrogen fertilizations, in which the peaks were registered on the $3^{\text {rd }}$ $\left(8.4 \mathrm{~kg} \mathrm{~N} \mathrm{ha}^{-1}\right)$ and $2^{\text {nd }}\left(11.1 \mathrm{~kg} \mathrm{~N} \mathrm{ha}^{-1}\right)$ days after the $1^{\text {st }}$ and $2^{\text {nd }} \mathrm{N}$ fertilization, respectively (Figures $2 \mathrm{~b}$ and $3 \mathrm{~b}$ ).

The accumulated rainfall 42 days after the $3^{\text {rd }}$ fertilization was $192.5 \mathrm{~mm}$. In the first two days and on the 4th day, there was no rainfall; on the $3^{\text {rd }}$ and $5^{\text {th }}$ days, the rainfall was 4.0 and $9.2 \mathrm{~mm}$, respectively. However, the soil moisture measured at the time of collection was $21.1 ; 18.5 ; 21.9 ; 19.1$; and $22.3 \%$ for the first five days. In the same period, the average air temperature was $23.2^{\circ} \mathrm{C}$ and that of the soil was $22.0 ; 22.5 ; 21.4 ; 21.8$; and $21.2{ }^{\circ} \mathrm{C}$ (Figure $4 \mathrm{c}$ ). On the $1^{\text {st }}$ $(71 \%)$ and $2^{\text {nd }}(72 \%)$ days after the $3^{\text {rd }} \mathrm{N}$ fertilization, the air relative humidity was maintained below the critical relative humidity for urea. However, from the $3^{\text {rd }}$ to the $9^{\text {th }}$ day (78; $79 ; 86 ; 91 ; 89 ; 92$; and $88 \%$ ), the relative air humidity was higher than the critical relative humidity for urea.

It is important to stress that on the $2^{\text {nd }}$ day after fertilization, there was also a significant loss of $\mathrm{N}^{-\mathrm{NH}_{3}}$ $\left(7.8 \mathrm{~kg} \mathrm{~N} \mathrm{ha}^{-1}\right)$ for urea, followed by a reduction on the $3^{\text {rd }}$ day $\left(4.8 \mathrm{~kg} \mathrm{~N} \mathrm{ha}^{-1}\right)$ and the maximum value on the $4^{\text {th }}$ day $\left(8.7 \mathrm{~kg} \mathrm{~N} \mathrm{ha}^{-1}\right)$. This variation may be linked to the drying/evaporation process of the soil.

One day before the application of $\mathrm{N}$ fertilizers, the irrigation system was turned on and provided a depth of water equal to $9 \mathrm{~mm}$, followed by a dry period of three days (period of decreased soil moisture). On the $3^{\text {rd }}$ day after the application of $\mathrm{N}$ fertilizers, there was a record $4 \mathrm{~mm}$ of rainfall, which promoted an increase in soil moisture from the second $(\mathrm{U}=18.8 \%)$ to the third $(\mathrm{U}=21.9 \%)$ day and a subsequent decrease in moisture on the fourth day $(\mathrm{U}=$ $19.1 \%$ ) (without rainfall).

These results corroborate those reported by Engel, Jones and Wallander (2011), who found greater losses of $\mathrm{N}^{-\mathrm{NH}_{3}}$ (30 to $44 \%$ of $\mathrm{N}$ applied) when urea was applied to the soil surface with a high moisture content followed by a slow drying period, with either little or no rainfall. Thus, the greatest loss of $\mathrm{N}_{-} \mathrm{NH}_{3}$ occurs when the soil surface is drying, that is, the evaporation rate is more important than the initial moisture condition (Lara Cabezas; Trivelin; Boaretto, 1992).

The total loss of $\mathrm{N}^{-\mathrm{NH}_{3}}$ (total of $\mathrm{N}$ fertilizations in each treatment) was influenced $(\mathrm{p} \leq 0.05)$ by the nitrogen fertilizers when topdressed-applied to a coffee orchard (Table 3).

The accumulated loss of N-NH $\left(\mathrm{kg} \mathrm{ha}^{-1}\right)$ in the three fertilizations for nitrogen fertilizers followed the decreasing order: urea $\left(83.2 \mathrm{~kg} \mathrm{~N} \mathrm{ha}^{-1}\right)>$ Polyblen Extend ${ }^{\circledR}-100 \%$ (60.3 $\mathrm{kg} \mathrm{N}$ ha $\left.{ }^{-1}\right)>$ Polyblen Montanha $^{\circledR}-100 \%\left(46.8 \mathrm{~kg} \mathrm{~N} \mathrm{ha}^{-1}\right)>$ Polyblen Extend ${ }^{\circledR}-70 \%\left(35.1 \mathrm{~kg} \mathrm{Nha}^{-1}\right)>$ Polyblen Montanha $^{\circledR}$ $-70 \%\left(24.2 \mathrm{~kg} \mathrm{~N} \mathrm{ha}^{-1}\right)>$ ammonium nitrate $\left(2.0 \mathrm{~kg} \mathrm{~N} \mathrm{ha}^{-1}\right)$.
The total accumulated $\mathrm{N}-\mathrm{NH}_{3}$ losses with the application of urea as a percentage of $\mathrm{N}$ applied was $18.5 \%$ (83.2 $\mathrm{kg} \mathrm{N} \mathrm{ha}^{-1}$ ), a figure that approaches that reported by Fenilli et al. (2007) of $21 \%$ of the total $\mathrm{N}$ applied to a coffee orchard. The authors used the dose of $280 \mathrm{~kg}$ $\mathrm{N} \mathrm{ha}^{-1}$ split into four applications of $70 \mathrm{~kg} \mathrm{~N} \mathrm{ha}^{-1}$ each. Losses of 31.2 and $1.0 \%$ of the total $\mathrm{N}$ applied as urea and ammonium nitrate, respectively, were reported by Dominghetti et al. (2016).

The lower loss of $\mathrm{N}$ by urea compared to those reported by these authors may be ascribed to the use of irrigation and to the high rainfall recorded in southern Minas Gerais state in the 2014/2015 growing season. The greater water availability under the experimental conditions may have contributed to an incorporation of part of the urea into the soil and hence reduced the losses of $\mathrm{N}$ into the atmosphere.

The largest $\mathrm{N}-\mathrm{NH}_{3}$ losses of Polyblen Extend ${ }^{\circledR}$ 100\% (applied dose: $450 \mathrm{~kg} \mathrm{~N} \mathrm{ha}^{-1}$ ) relative to those of Polyblen Extend ${ }^{\circledR}$ - 70\% (applied dose: $315 \mathrm{~kg} \mathrm{~N} \mathrm{ha}^{-1}$ ) and Polyblen Montanha ${ }^{\circledR}$ - 100\% (applied dose: $450 \mathrm{~kg} \mathrm{~N} \mathrm{ha}^{-1}$ ) compared to Polyblen Montanha ${ }^{\circledR}-70 \%$ (applied dose: 315 $\mathrm{kg} \mathrm{N} \mathrm{ha}^{-1}$ ) may be associated with a higher concentration of fertilizer per area applied. This increased concentration of the fertilizer per soil area causes urease to act more intensely on the hydrolysis of urea (Vitti et al., 2007).

A study evaluating the kinetic parameters of urea hydrolysis in southern Minas Gerais state soils showed an increase in the rate of hydrolysis of urea with an increasing concentration of fertilizer but that was not proportional to the rates of N applied (Santos; Valle; Santos, 1991).

In the hydrolysis reaction, there is a consumption of $\mathrm{H}^{+}$from the medium; thus, the $\mathrm{pH}$ of the soil tends to remain highest in the place where fertilizer is concentrated, which promotes the volatilization of $\mathrm{N}-\mathrm{NH}_{3}$, particularly with increasing urea rates (Vitti et al., 2007). Higher rates or localized applications (higher concentration of fertilizer per area) tend to result in greater $\mathrm{N}_{-} \mathrm{NH}_{3}$ losses (Cantarella, 2007). There were higher rates of $\mathrm{N}^{-\mathrm{NH}_{3}}$ losses at the highest $\mathrm{N}$ rates applied (180 $\left.\mathrm{kg} \mathrm{N} \mathrm{ha}^{-1}\right)$ compared to the lowest dose of $\mathrm{N}\left(60 \mathrm{~kg} \mathrm{~N} \mathrm{ha}^{-1}\right)$ in Central-Southern Paraná. The increase in $\mathrm{N}-\mathrm{NH}_{3}$ losses was not proportional to the increase in the rate applied (Rojas et al., 2012).

The urea blends stabilized with NBPT and coated with $\mathrm{S}^{0}+$ polymers (Polyblen Extend ${ }^{\circledR}$ and Polyblen Montanha ${ }^{\circledR}$ ) promoted a reduction in ammonia volatilization compared to urea (uncoated). The coating with polymers caused a decrease in $\mathrm{N}-\mathrm{NH}_{3}$ losses due to reducing the contact of the nutrient inside the granule with the humidity in the air and the soil moisture. This causes a smaller 
concentration of urea to be hydrolyzed all at once, which reduces the accumulation of $\mathrm{N}^{-\mathrm{NH}_{4}^{+}}$in the soil, thereby reducing the risk of forming $\mathrm{N}-\mathrm{NH}_{3}$ (Peng et al., 2015).

The reduced contact of the fertilizer with the soil and the atmosphere varied depending on the thickness, type and quality of the coating, as well as on the environmental conditions (temperature and humidity). Thus, the greater thickness of the coating of Polyblen Montanha ${ }^{\circledR}$ compared to Polyblen Extend ${ }^{\circledR}$ (Figure 1) allows for a greater delay in the dissolution of urea.

As reported by Detrick et al. (2002), the covering with com $\mathrm{S}^{0}$ must have a minimum thickness of $40 \mu \mathrm{m}$ or 13 to $14 \%$ of $\mathrm{S}^{0}$ in relation to the weight of the final blend. However, due to variation in the distribution of the pulverized $\mathrm{S}^{0}$ in the melted form for coating the urea granules at the end of the production process, the coated urea granules showed variation in thickness: fine $(<30$ $\mu \mathrm{m})$, medium (30 and $50 \mu \mathrm{m})$ and thick $(>50 \mu \mathrm{m})$. Due to this lack of uniformity in the thickness of the $\mathrm{S}^{0}$ layer, the adding of a sealant or coating avoids the too-rapid release of a fraction of urea and the too-slow release of another fraction with a thicker coating. These authors further reported that different compounds applied in varying proportions promoted differences in the $\mathrm{N}$ release time (standard temperature $\left.30^{\circ} \mathrm{C}\right)$ : urea coating $(2.4 \mathrm{~mm}$ in diameter) with $4 \%$ of polymers $=4$ to 6 weeks; $12 \%$ of polymers $=12$ to 18 weeks; $\mathrm{S}^{0}=2$ weeks; $10 \%$ of $\mathrm{S}^{0}$ $+2 \%$ of polymers $=6$ weeks; and $2 \%$ of polymer "a" + $8 \%$ of $\mathrm{S}^{0}+2 \%$ polymer "b" $=14-16$ weeks.

In addition, polymers can improve the physical characteristics of the fertilizers coated with $\mathrm{S}^{0}$ because they promote increased consistency, abrasion resistance, friction and impact (dust formation tendency), avoiding the disruption of $\mathrm{S}^{0}$ layer during the handling of the coated urea from its production until the moment of application. The layers of polymers or resins also act as barriers to the entrance of water into the granule, thereby reducing its hygroscopicity (Chen et al., 2011).

For the SPAD index, the foliar $\mathrm{N}$ content in the beginning (11/20/2014) and at harvesting $(07 / 15 / 15)$ was not significantly different $(\mathrm{p} \leq 0.05)$ between treatments when applied as a topdressing to the coffee crop (Table 4).

The mean leaf nitrogen contents in the present study are within the standard considered suitable for coffee crop production in the sampled seasons, according to the recommendations of Malavolta, Vitti and Oliveira (1997). Therefore, there were no major variations in the $\mathrm{N}$ contents between the treatments and assessed seasons, even with high amounts of losses of the nutrient by volatilization in some treatments.

For yield (bags ha-1), there was also no significant differences $(p \leq 0.05)$ between treatments applied as a topdressing to the coffee crop. The yield in grains of coffee was $83.16 ; 82.03 ; 81.85 ; 81.1 ; 79.6$; and 77.1 bags ha $^{-1}$ for ammonium nitrate, Polyblen Extend ${ }^{\circledR}-70 \%$, Polyblen Montanha ${ }^{\circledR}-70 \%$, Polyblen Extend ${ }^{\circledR}-100 \%$, Urea and Polyblen Montanha ${ }^{\circledR}-100 \%$, respectively.

In the assessment of yield (liters of harvested coffee/bag of benefited coffee), there were significant differences $(p \leq 0.05)$ between treatments with nitrogen fertilizers applied as a topdressing to the coffee crop. Treatments with ammonium nitrate (505.2 liters of harvested coffee/bag of benefited coffee), Polyblen Extend $^{\circledR}-100 \%$ (502.42 liters of harvested coffee/bag of

Table 3: Accumulated $\mathrm{N}-\mathrm{NH}_{3}$ losses/agricultural year from fertilizers (conventional urea, ammonium nitrate, Polyblen Extend ${ }^{\circledR}$ and Polyblen Montanha ${ }^{\circledR}$ ) in 2014/2015.

\begin{tabular}{|c|c|c|c|c|}
\hline \multirow[b]{2}{*}{ Treatments } & \multicolumn{4}{|c|}{$\mathrm{N}-\mathrm{NH}_{3}$ losses $\left(\mathrm{kg} \mathrm{ha}^{-1} \mathrm{~N}\right)$} \\
\hline & $\begin{array}{c}\text { After } 1^{\text {st }} \\
\text { Fertilization }\end{array}$ & After $2^{\text {nd }}$ Fertilization & $\begin{array}{c}\text { After } 3^{\text {rd }} \\
\text { Fertilization }\end{array}$ & Accumulated losses \\
\hline Urea (100\%) & $23.2 \mathrm{~b}$ & $32.8 \mathrm{a}$ & $27.4 a$ & $83.4 \mathrm{a}$ \\
\hline Ammonium nitrate (100\%) & $0.9 c$ & $0.6 \mathrm{e}$ & $0.7 \mathrm{~b}$ & $2.2 \mathrm{f}$ \\
\hline Polyblen Extend ${ }^{\circledR}(100 \%)$ & $38.8 \mathrm{a}$ & $21.4 \mathrm{~b}$ & - & $60.2 \mathrm{~b}$ \\
\hline Polyblen Extend ${ }^{\circledR}$ (70\%) & $23.1 \mathrm{~b}$ & $11.6 \mathrm{c}$ & - & $34.7 d$ \\
\hline Polyblen Montanha ${ }^{\circledR}(100 \%)$ & $41.9 \mathrm{a}$ & $5.5 \mathrm{~d}$ & - & $47.4 \mathrm{c}$ \\
\hline Polyblen Montanha ${ }^{\circledR}$ (70\%) & $20.0 \mathrm{~b}$ & $4.3 \mathrm{~d}$ & - & $24.3 \mathrm{e}$ \\
\hline Mean & 24.7 & 12.7 & 4.7 & 42.11 \\
\hline Coefficient of variation (\%) & 8.4 & 9.1 & 23.1 & 6.1 \\
\hline
\end{tabular}

The equal letters do not differ from one another by the Skott-Knott test at 5\% significance level. 
Table 4: SPAD index, $N$ content $\left(\mathrm{dag} \mathrm{kg}^{-1}\right)$ in the beginning of the experiment and $\mathrm{N}$ content $\left(\mathrm{dag} \mathrm{kg}^{-1}\right)$ at the time of the harvesting with the $F$ test values, as affected by treatments applied in topdressing in the coffee crop.

\begin{tabular}{|c|c|c|c|}
\hline Treatments & SPAD index & $\mathrm{N}$ content - (Beginning) (dag kg-1) & $\mathrm{N}$ content - (Harvest) $\left(\right.$ dag kg $\left.^{-1}\right)$ \\
\hline Urea (100\%) & $74.1 \mathrm{a}$ & $3.23 \mathrm{a}$ & $3.03 a$ \\
\hline Ammonium nitrate (100\%) & $75.3 \mathrm{a}$ & $3.33 a$ & $3.10 \mathrm{a}$ \\
\hline Polyblen Extend ${ }^{\circledR}(100 \%)$ & $74.8 \mathrm{a}$ & $3.30 \mathrm{a}$ & $3.00 \mathrm{a}$ \\
\hline Polyblen Extend ${ }^{\circledR}(70 \%)$ & $73.3 \mathrm{a}$ & $3.20 \mathrm{a}$ & $3.13 \mathrm{a}$ \\
\hline Polyblen Montanha ${ }^{\circledR}(100 \%)$ & $74.2 \mathrm{a}$ & $3.20 \mathrm{a}$ & $3.00 \mathrm{a}$ \\
\hline Polyblen Montanha ${ }^{\circledR}$ (70\%) & $73.3 \mathrm{a}$ & $3.16 \mathrm{a}$ & $3.00 \mathrm{a}$ \\
\hline Mean & 72.0 & 3.21 & 2.98 \\
\hline Variation coefficient (\%) & 5.23 & 3.91 & 6.30 \\
\hline Fcalc (ANOVA) & 7.4 & 1.47 & 3.02 \\
\hline
\end{tabular}

Means followed by the same letters in the columns do not differ from each other at $5 \%$ of probability by Skott-Knott test.

benefited coffee), Polyblen Extend ${ }^{\circledR}-70 \%$ (496.5 liters of harvested coffee/bag of benefited coffee), Polyblen Montanha ${ }^{\circledR}-100 \%$ (507.2 liters of harvested coffee/bag of benefited coffee) and Polyblen Montanha ${ }^{\circledR}-70 \%$ (506.6 liters of harvested coffee/bag of benefited coffee) presented similar incomes and a lower income index compared to that of treatment with urea (527.4 liters of harvested coffee/ bag of benefited coffee). That is, for treatment with the application of urea, in which there was a higher loss of $\mathrm{N}$ by volatilization, more harvested coffee was required to produce a bag of benefited coffee.

However, for income (liters of coffee in coconut/ bag of benefited coffee), there were no significant differences $(p \leq 0.05)$ between treatments applied as a topdressing to the coffee crop. The mean values of income were $284.7 ; 284.6 ; 282.7 ; 280.2 ; 271.3$; and 270.5 liters of coffee in coconut/bag of benefited coffee for urea, Polyblen Extend ${ }^{\circledR}-70 \%$, ammonium nitrate, Polyblen Montanha $^{\circledR}-70 \%$, Polyblen Extend ${ }^{\circledR}-100 \%$ and Polyblen Montanha ${ }^{\circledR}-100 \%$, respectively.

For sorting by sieve, in big shot flat grain, medium flat grain, kid flat grain and "moca" grain, there were no significant differences $(\mathrm{p} \leq 0.05)$ between treatments with conventional $\mathrm{N}$ fertilizers and controlled or slow $\mathrm{N}$ fertilizers applied as topdressing to the coffee crop.

The mean values as a percentage of big shot flat grains were $14.2 ; 12.1 ; 11.6 ; 11.0 ; 10.5$; and $9.4 \%$ for ammonium nitrate, Polyblen Montanha ${ }^{\circledR}-70 \%$, Polyblen Montanha $^{\circledR}-100 \%$, Polyblen Extend ${ }^{\circledR}-70 \%$, Polyblen Montanha $^{\circledR}-100 \%$ and Urea, respectively. For medium flat grains, the values were $56.8 ; 53.8 ; 52.9 ; 52.7 ; 49.9$; and $47.9 \%$ for Polyblen Montanha 70\%, Polyblen Montanha
$100 \%$, Polyblen Extend 70\%, ammonium nitrate, Polyblen Extend $100 \%$ and urea, respectively.

The mean values of kid flat grain were 15.8; 13.8; $11.4 ; 11.2 ; 10.6$; and 9.7\% for urea, Polyblen Extend ${ }^{\circledR}-70 \%$, Polyblen Extend ${ }^{\circledR}-100 \%$, Polyblen Montanha ${ }^{\circledR}-70 \%$, Polyblen Montanha ${ }^{\circledR}-100 \%$ and ammonium nitrate, respectively. For "moca" grain, the values were 27.1; 25.3; 23.7; 22.6; 21.3; and $19.0 \%$ for Polyblen Extend ${ }^{\circledR}-100 \%$, Urea, Polyblen Montanha ${ }^{\circledR}-100 \%$, ammonium nitrate, Polyblen Extend ${ }^{\circledR}-70 \%$ and Polyblen Montanha ${ }^{\circledR}-70 \%$, respectively.

The lack of difference observed between treatments for yield, income and sorting by sieve may be associated with the leaf $\mathrm{N}$ content. The $\mathrm{N}$ contents varied from 3.0 to $3.1 \mathrm{dag} \mathrm{kg}^{-1}$, and according to many studies, the critical range of leaf $\mathrm{N}$ contents in coffee crop production is between 2.3 and $3.5 \mathrm{dag} \mathrm{kg}^{-1}$ (Malavolta; Vitti; Oliveira, 1997).

It has been suggested that the amount of organic matter in the soil prior to the beginning of treatments (3.2 $\mathrm{g} \mathrm{kg}^{-1}$ ), associated with the high dose of nitrogen used in the treatment with urea $\left(450 \mathrm{~kg} \mathrm{~N} \mathrm{ha}^{-1}\right)$, which had a higher loss, contributes to the amount of $\mathrm{N}$ needed by plants, thereby avoiding possible deficiencies and maintaining an adequate $\mathrm{N}$ content in the leaves.

According to Ribeiro et al. (1999), the recommendations of nitrogen application to crops, there including coffee crop, are achieved by accounting for losses in the range of $50 \%$ of nitrogen by volatilization due to the general use of urea in agriculture. In this way, the application of sources in which losses are greatly reduced, such as Polyblen Montanha ${ }^{\circledR}$ may require only $70 \%$ of the recommended dose by Ribeiro et al. (1999) as a unique application without changing the nutrition or yield. 


\section{CONCLUSIONS}

Ammonium nitrate promotes the lowest $\mathrm{N}-\mathrm{NH}_{3}$ losses by volatilization, irrespective of the climatic conditions after each nitrogen fertilization. Polyblen Extend ${ }^{\circledR}$ and Polyblen Montanha ${ }^{\circledR}$ reduced losses of $\mathrm{N}$ compared to conventional urea, with Polyblen Montanha ${ }^{\circledR}$ being more efficient than Polyblen Extend ${ }^{\mathbb{B}}$. The increased dose of $\mathrm{N}$ of either Polyblen Extend ${ }^{\circledR}$ or Polyblen Montanha ${ }^{\circledR}$ increased the losses of $\mathrm{N}$ by volatilization. Although treatment with the application of urea presented a high loss of $\mathrm{N}(18.5 \%$ of $\mathrm{N}$ applied), the nutrition and yield of coffee crop was not affected because these factors may be influenced by the fertilization of the previous season. Therefore, when planning for nitrogen fertilization, one should consider many factors, such as the cost of fertilizers and staff for fertilizer application and the fact that the use of Polyblen Montanha ${ }^{\circledR}$ combines the two splittings of conventional sources, such as urea and ammonium nitrate, into one by applying only $70 \%$ of the recommended dose without affecting the coffee crop yield or nutrition.

\section{REFERENCES}

ALVARES, C. A. et al. Köppen's climate classification map for Brazil. Meteorologische Zeitschrift. 22(6):711-728, 2013.

ASSOCIAÇÃO NACIONAL PARA DIFUSÃO DE ADUBOS - ANDA. Anuário Estatístico do Setor de Fertilizantes. São Paulo, ANDA, 1987-2015. 176p.

AZEEM, B. et al. Review on materials \& methods to produce controlled release coated urea fertilizer. Journal of Controlled Release. 181:11-21, 2014.

BRASIL. Instrução Normativa n 8, de 11 de Junho de 2003. Regulamento técnico de identidade e de qualidade para a classificação do café beneficiado grão cru. Diário Oficial da República Federativa do Brasil, Ministério da Agricultura, Pecuária e Abastecimento. Brasília, DF, 13 jun. 2003. Seção 1, p. 22-29.

BRUNO, I. P. et al. Fertilizer nitrogen in fertigated Coffee crop: Absorption changes in plant compartments over time. Field Crop Research. 124:369-377, 2011.

BUOL, S. W. et al. Soil genesis and classification, 6. ed. WileyBlackwell, Ames. 2011.

CANTARELLA, H. Nitrogênio. In: NOVAIS, R. F. et al. (Ed.). Fertilidade do Solo. Viçosa, Sociedade Brasileira de Ciência do Solo. 2007. p.375-470.
CARELLI, M. L. C.; FAHL, J. I.; RAMALHO, J. D. C. Aspects of nitrogen metabolism in coffee plants. Brazilian Journal of Plant Physiology. 18:(1):9-21, 2006.

$\mathrm{CHEN}, \mathrm{H}$. et al. Water soluble alkyd resin-sulfur coated controlled release fertilizer and preparation thereof. US Pat. 2011/0072871 A1, 2011

CHIEN, S. H.; PROCHNOW, L. I.; CANTARELLA, H. Recent developments of fertilizer production and use to increase nutrient efficiency and minimize environmental impacts. Advances in Agronomy. 102:261-316, 2009.

COMISSÃO DE FERTILIDADE DO SOLO DO ESTADO DE MINAS GERAIS - CFSEMG. Recomendações para o uso de corretivos e fertilizantes em Minas Gerais - $5^{a}$ Aproximação. Viçosa, 1999. 310p.

CREW, T. E.; PEOPLES, M. B. Can the synchrony of nitrogen supply and crop demand be improved in legume and fertilizer base agroecossystems? A review. Nutrient Cycling in Agroecossystem. 72:101-120, 2005.

DANTAS, A. A. A.; CARVALHO, L. G.; FERREIRA, E. Classificação e tendências climáticas em Lavras, MG. Ciência e Agrotecnologia. 31(6):1862-1866, 2007.

DETRICK, J. H.; HARGROVE, G. L. Polymer-sulfur-polymer coated fertilizers. US Pat. 6338746 B1, 2002. 6p.

DOMINGHETTI, A. W. et al. Nitrogen loss by volatilization of nitrogen fertilizers applied to coffee orchard. Ciência e Agrotecnologia. 40:(2)1-11, 2016.

DU, C.; ZHOU, J.; SHAVIV, A. Release characteristics of nutrients from polymer-coated compound controlled release fertilizers. Journal of Polymers and Environment. 14(3):223-230, 2006.

DU, C. et al. Prediction of nitrate release from polymercoated fertilizers using an artificial neural network model. Biosystems Engineering. 99(4):478-486, 2008.

EMPRESA BRASILEIRA DE PESQUISA AGROPECUÁRIA EMBRAPA, Sistema brasileiro de classificação de solos, third ed. Embrapa Solos, Rio de Janeiro, 2013. 353p.

ENGEL, R.; JONES, C.; WALLANDER, R. Ammonia volatilization from urea and mitigation by NBPT following surface application to cold soils. Nutrient Management \& Soil \& Plant Analysis. 75:2348-2357, 2011.

FAN, X. H.; LI, Y. C. Nitrogen release from slow-release fertilizers as affect by soil type and temperature. Soil Science Society American Journal. 74:1635-1641, 2010.

FENILLI, T. A. B. et al. Volatilization of ammonia derived from fertilizer and its reabsorption by coffee plants. Communications in Soil Science and Plant Analysis. 38:1741-1751, 2007. 
FERNANDES, J. C. et al. Sources and rates of nitrogen fertilizer used in Mombasa guineagrass in the Brazilian Cerrado region. African Journal of Agricultural Research. 10:1031-1042, 2015.

FERREIRA, D. F. Sisvar: A computer statistical analysis system. Ciência e Agrotecnologia. 35(6):1039-1042, 2011.

FUNJINUMA, R.; BALSTER, N. J.; NORMAM, J. M. An improved model of nitrogen release for surface-applied urea controlled-released fertilizer. Soil Science Society of American Journal. 73:2043-2050, 2009.

GRANT, C. A. et al. Crop yield and nitrogen concentration with controlled release urea and split applications of nitrogen as compared to non-coated urea applied at seeding. Field Crops Research. 127:170-180, 2012.

GUIMARÃES, P. T. G. et al. (Ed.). Recomendações para o uso de corretivos e fertilizantes em Minas Gerais, $\mathbf{5}^{\mathbf{a}}$ Aproximação. Viçosa, MG: Comissão de Fertilidade do Solo do Estado de Minas Gerais - CFSEMG, 1999. p. 289-302.

HARGROVE, W. L. et al. Comparison of a forced-draft technique to $15 \mathrm{~N}$ recovery for measuring ammonia volatilization under field conditions. Soil Science Society American Journal. 51(1):124-128, 1987.

THE INTERNATIONAL FERTILIZER INDUSTRY ASSOCIATION - IFA. The global " $4 R$ " nutrient stewardship framework for developing and delivering fertilizer best management practices, Paris, 2009. 10p.

JIN, S. et al. Preparation and properties of a degradable interpenetrating polymer networks based on starch with water retention, amelioration of soil, and slow release of nitrogen and phosphorus fertilizer. Journal of applied Polymer Science. 128:407-415, 2013.

LARA-CABEZAS, W. A. R.; KORNDÖRFER, G. H.; MOTTA, S. A. Volatilização de $\mathrm{N}-\mathrm{NH}_{3}$ na cultura de milho: I. Efeito da irrigação e substituição parcial da ureia por sulfato de amônio. Revista Brasileira de Ciência do Solo. 21:481487, 1997.

LARA-CABEZAS, W. A. R.; TRIVELIN, P. C. O.; BOARETTO, A. E. Efeito do tamanho do grânulo e relação N/S da ureia aplicada em superfície na volatilização de amônia sob diferentes umidades iniciais do solo. Revista Brasileira de Ciência do Solo. 14:409-4013, 1992.

MALAVOLTA, E.; VITTI, G. C.; OLIVEIRA, S. A. Avaliação do estado nutricional das plantas: Princípios e aplicações. 2. ed. Piracicaba: POTAFOS, 1997. 319 p.

MARTINEZ, H. E. P et al. Nutrição mineral do cafeeiro e qualidade da bebida. Revista Ceres. 61:838-848, 2014.
McINNES, K. J. et al. Field measurements of ammonia loss from surface applications of urea solution to bare soil. Agronomy Journal. 78:192-196, 1986.

NOELLSCH, A. J. et al. Corn response to conventional and slowrelease nitrogen fertilizers across a clay plan landscape. Agronomy Journal. 101:607-614, 2009.

PENG, X. et al. Laboratory evaluation of ammonia volatilization and nitrate leaching following nitrogen fertilizer application on a coarse-textured soil. Agronomy Journal. 107:871879, 2015.

RIBEIRO, A. C. et al. (Ed.). Recomendações para o uso de corretivos e fertilizantes em Minas Gerais: $5^{a}$ Aproximação. Viçosa, MG: Comissão de Fertilidade do Solo do Estado de Minas Gerais - CFSEMG, 1999. 180 p.

ROCHETTE, P. et al. Ammonia volatilization an nitrogen retention: How deep to incorporate urea? Journal Environmental Quality. 42(6):1635-42, 2014.

ROJAS, C. A. L et al. Volatilização de amônia da ureia alterada por sistemas de preparo de solo e plantas de cobertura invernais no centro-sul do Paraná. Revista Brasileira de Ciência do Solo. 36: 261-270. 2012.

ROY, A. H.; HAMMOND, L. L. Challenges and opportunities for the fertilizer industry. In: MOSIER, A. R. et al. (ed.) Agriculture and the nitrogen cycle. Island Press, Washington, DC. p. 231-241, 2004.

SANTOS, A. R.; VALLE, F. R.; SANTOS, J. A. G. Avaliação de parâmetros cinéticos da hidrólise da uréia em solos do Sul de Minas Gerais. Revista Brasileira de Ciência do Solo. 15:309-313, 1991.

TIMILSENA, Y. P. et al. Enhanced efficiency fertilisers: A review of formulation and nutrient release patterns. Journal of the Science and Food Agriculture. 95:1131$1142,2015$.

TRENKEL, M. E. Slow- and Controlled-Release and Stabilized Fertilizers. An Option for Enhancing Nutrient Use Efficiency in Agriculture. Paris, France: International Fertilizer Industry Association, 2010. p. 163.

VIEIRA, G. H. S. et al. Custo da irrigação do cafeeiro em diferentes tipos de equipamento e tamanhos de área. Engenharia na Agricultura, 19:53-61, 2011.

VITTI, A. C. et al. Produtividade da cana-de-açúcar relacionada à localização de adubos nitrogenados aplicados sobre os resíduos culturais em canavial sem queima. Revista Brasileira de Ciência do Solo, 31(3):491-498, 2007. 